\title{
KARAKTERISASI Al-Zn7 HASIL PELEBURAN DAPUR CRUCIBLE DENGAN TIPE PENUANGAN TUNGKIK
}

\author{
Ipung Kurniawan'), Bayu Aji Girawan'), Imam Yulianto ${ }^{3)}$ \\ ${ }^{1) 2) 3)}$ Jurusan Teknik Mesin, Politeknik Negeri Cilacap \\ Jln. Dr Soetomo No 1, Sidakaya, Cilacap \\ ipung.k.poltec@gmail.com
}

\begin{abstract}
Abstrak
Kata Kunci:

Dapur Crucible,

Aluminium,

Struktur Mikro,

Kekerasan.

Aluminium saat ini banyak digunakan dan dimanfaatkan dalam kegiatan industri karena sifatnya yang ringan dan memiliki kekuatan mekanis yang baik. Pemanfaatan aluminium tidak harus terbatas pada pemanfaatan aluminium yang baru tetapi juga pada aluminium bekas. Tujuan utama dari penelitian ini adalah 1) Pengujian sifat fisis dan mekanik Al-Zn7 dari peleburan dapur crucible 2) Menganalisa dapur crucible peleburan Al-Zn7 dengan membandingkan hasil peleburan pertama dan kedua. Metode yang digunakan dalam penelitian ini adalah studi eksperimen dan studi pustaka. Hasil pengujian kekerasan menggunakan metode Rockwell dengan nilai rata-rata masing-masing pengecoran pertama adalah 49,2 HRB dan pengecoran kedua adalah 50,3 HRB. Berdasarkan hasil pengujian menunjukkan bahwa kualitas dapur crucible baik karena tidak mengalami perubahan yang signifikan.
\end{abstract}

\begin{tabular}{|c|c|}
\hline & Abstract \\
\hline $\begin{array}{l}\text { Keywords: } \\
\text { Crucible furnace, } \\
\text { Alumunium, Micro } \\
\text { structure, hardness }\end{array}$ & $\begin{array}{l}\text { Nowdays, Alumunium is widely used and utilized in industrial activities because of light properties } \\
\text { and having well mechanical strengths. The use of alumunium does not only limit on the use of new } \\
\text { alumunium, but also the used one. The main purpose of this research, i.e., (1) testing of physical and } \\
\text { mechanical properties of Al-Zn7 from the fussion of Crucible furnace; (2) analyzing crucible furnace of } \\
\text { the Al-Zn7 fussion by comparing to the result of the first and second fussion. The method of this } \\
\text { research was experimental research with the average value of each the first casting was } 49,2 \text { HRB and } \\
\text { the second one was 50,3 HRB. Based on the test result showed that the quality of crucible furnace was } \\
\text { good because it did not experience the significant changes. }\end{array}$ \\
\hline
\end{tabular}

\footnotetext{
Alamat korespondensi :

E-mail : ipung.k.poltec@gmail.com

ISSN : $2087-1627$
} 


\section{PENDAHULUAN}

\section{Latar Belakang}

Industri logam khususnya pengecoran logam mempunyai peranan yang sangat penting dalam menunjang pembangunan saat ini. Berkembangnya industri di Indonesia menjadikan kebutuhan akan industri logam juga meningkat. Salah satu contoh adalah, saat ini sentra-sentra industri pengecoran menengah-kecil (UKM) banyak tersebar di Propinsi Jawa Tengah seperti Klaten, Pati, Tegal dan Surakarta.

Umumnya industri kecil pengecoran logam sekarang ini tidak menggunakan aluminium murni (aluminum ingot) sebagai bahan dasar, namun menggunakan material bekas/rongsokan (sekrap) dan komponen yang rusak (reject materials) dari pengecoran sebelumnya, yang dalam hal ini dikenal dengan proses tuang ulang (remelting) untuk memenuhi kebutuhan pasar seperti halnya komponen otomotif [1].

Perlu diketahui bahwa setiap komponen otomotif harus memenuhi persyaratan mekanik tertentu. Seperti halnya beban berulang dan kadangkadang beban kejut maka komponen tersebut harus mendapatkan jaminan terhadap kerusakan akibat retak-lelah, aman dalam penggunaan atau bahkan mempunyai usia pakai (life time) yang lebih lama. Sehingga karakteristik materaial aluminium dari bahan bekas (reject) sangat penting untuk diketahui dan ditingkatkan [1].

Berdasarkan permasalahan diatas diperlukan kajian yang mendalam tentang pengujian material hasil peleburan aluminium bekas serta analisa dapur peleburan ketika penggunaan dilakukan secara berulang. Untuk itu pembahasan tentang karakterisasi $\mathrm{Al}-\mathrm{Zn}_{7}$ hasil peleburan dapur crucible dengan tipe penuangan tungkik diangkat sebagai topik dalam penelitian ini.

\section{Tujuan Penelitian}

Tujuan utama dari penelitian ini adalah:

a. Melakukan pengujian sifat fisis dan mekanik Al$\mathrm{Zn}_{7}$ dari peleburan dapur crucible

b. Melakukan analisa dapur crucible dari peleburan $\mathrm{Al}-\mathrm{Zn}_{7}$ dengan membandingkan hasil peleburan pertama dan kedua.

\section{Manfaat Penelitian}

Manfaat dari penelitian ini adalah menambah khasanah ilmu pengetahuan tentang ilmu pengujian material $\mathrm{Al}_{-} \mathrm{Zn}_{7}$ hasil peleburan dengan dapur crucible sehingga diharapkan proses pemanfaatan dapur crucible bisa menghasilkan produk sebagai barang produksi.

\section{Tinjauan Pustaka}

Penelitian tentang pengecoran ulang aluminium pernah dilakukan oleh beberapa peneliti. Beberapa diantaranya menghasilkan kesimpulan bahwa pengecoran ulang aluminium berpotensi meningkatkan jumlah porositas, menurunkan kekuatan dan kekerasan. Penelitian [2] untuk melakukan remelting aluminium paduan A320 $(72,37 \% \mathrm{Al}, 11,39 \% \mathrm{Si}, 6,82 \% \mathrm{Mg}, 2,77 \% \mathrm{Cu})$. Remelting dilakukan sebanyak tiga kali. Hasil uji tarik dan uji impak menunjukkan bahwa pengecoran ulang akan menurunkan kekuatan tarik, dan kekuatan impak.

Penelitian terhadap propeler dengan bahan aluminium bekas pernah dilakukan [3]. Penelitian dilakukan untuk mengetahui sifat propeler aluminium yang dibuat dengan proses pengecoran menggunakan crusibel berbahan bakar minyak dan dengan cetakan pasir. Sebelum peleburan, tidak dilakukan perhitungan dan pengukuran komposisi campuran bahan, namun sekedar perkiraan. Belum ada standar mutu yang dijadikan acuan untuk produk yang dihasilkan. Uji komposisi kimia dilakukan, dan menghasilkan data komposisi kimia bervariasi pada unsur-unsur dominannya, yaitu kandungan Al 68,02\%-74,38\%, Si 1,86-3,28\%, $\mathrm{Cu}$ 11,2-12,2\%, dan Mg 0-0,746\%. Nilai kekerasan material bervariasi dari $59 \mathrm{HRB}$ hingga $62 \mathrm{HRB}$.

Penelitian [4] dalam pengecoran ulang aluminium skrap salah satunya untuk menghasilkan bahan AlSi12 standar. Metode yang dilakukan dalam penghitungan komposisi awal bahan adalah menggunakan tabel simulasi dengan Ms. Excell. Skrap seberat 6000 gr sebagai bahan pengecoran terdiri dari $300 \mathrm{~g}$ piston, $300 \mathrm{~g}$ panci, $3000 \mathrm{~g}$ aluminium siku, $900 \mathrm{~g}$ aluminium plat, dan $1500 \mathrm{~g}$ master alloy AlSi49. Bahan-bahan tersebut dilebur sampai suhu $725 \mathrm{oC}$, diaduk selama 5 menit dengan penambahan covering flux, dan kemudian dituang dalam cetakan pasir. Uji komposisi dilakukan terhadap hasil pengecoran, dan didapatkan data komposisi yang bersesuaian dengan standar DIN EN1706. Hasil pengecoran mengandung porositas sebesar 1,88\%. Porositas yang ada dipicu oleh adanya unsur $\mathrm{Cu}$ sebagai unsur pemadu. Unsur $\mathrm{Cu}$ berperan meningkatkan kelarutan gas hidrogen. Disisi lain keuntungan penambahan $\mathrm{Cu}$ pada paduan aluminium adalah meningkatkan kekerasan bahan.

Penelitian lain [5] dalam pembuatan propeler untuk kapal kayu dari pengecoran ulang aluminium bekas untuk menghasilkan ADC3 dengan variasi penambahan TiB sebagai grain refiner dilakukan pada saat peleburan. TiB yang ditambahkan mempunyai kadar $\mathrm{Ti} 5 \%$ dan B $1 \%$. Metode perhitungan dengan simulasi Excel dilakukan untuk memperkirakan komposisi hasil pengecoran yang sesuai. Cetakan yang digunakan adalah cetakan pasir, dengan rongga cetakan silinder. Flux yang digunakan adalah garam yang berfungsi sebagai drossing flux. Suhu pelebur ditentukan 700 oC, sedangkan suhu penuangan ditentukan 650 oC. Pengujian yang dilakukan meliputi uji komposisi, uji densitas, uji kekerasan, uji tarik, dan uji struktur 
mikro. Spesimen uji tarik, uji kekerasan dan struktur mikro. Hasil penelitian diperoleh 1) Tingkat porositas 3,3\% sampai 5,9\% akibat penggunaan cetakan pasir. 2) Penambahan $\mathrm{TiB}$ sebanyak $0,5 \%$ ke ADC 3 hasil pengecoran aluminium bekas berpengaruh pada penurunan ukuran butir hingga $50 \%$, peningkatan kekerasan hingga 23\%, peningkatan kekuatan tarik hingga $11 \%$, serta penurunan keuletan hingga 20\%. 3) Nilai kekerasan dan kekuatan ADC 3 hasil pengecoran masih dibawah harga kekerasan dan kekuatan ADC 3 standar. 4) Struktur mikro yang terbentuk dari hasil pengecoran ADC 3 adalah $\alpha \mathrm{Al}$ dan $\mathrm{Si}$ eutectik yang merupakan struktur yang bisasa terbentuk pada paduan AlSi hipoeutektik dengan kadar Si kurang dari 12,5\%.

Aluminium merupakan material yang luas penggunaannya. Hal ini disebabkan karena Aluminium mempunyai sifat yang istimewa dibandingkan dengan logam lainnya. Diantara kelebihan Aluminium adalah: ringan, ulet, kuat, ketahanan korosi tinggi serta mempunyai konduktivitas panas dan daya hantar panas yang baik.

\section{Tabel 1 Sifat fisik Al [6]}

\begin{tabular}{ccccc} 
Element & Symbol & $\begin{array}{c}\text { Atomic } \\
\text { weight }\end{array}$ & $\begin{array}{c}\text { Melting } \\
\text { point }\left({ }^{\circ} \mathrm{C}\right)\end{array}$ & $\begin{array}{c}\text { Boiling } \\
\text { Point }\left({ }^{\circ} \mathrm{C}\right)\end{array}$ \\
Aluminium & Al & 26.97 & 660.4 & 2520 \\
\hline
\end{tabular}

\begin{tabular}{|c|c|c|c|c|}
\hline \multicolumn{2}{|c|}{$\begin{array}{l}\text { Latent heat of } \\
\text { fusion }\end{array}$} & \multicolumn{2}{|c|}{$\begin{array}{c}\text { Mean specific heat } \\
0-100^{\circ} \mathrm{C}\end{array}$} & \multirow{2}{*}{$\begin{array}{l}\text { Thermal } \\
\text { conductivity } \\
(\mathrm{W} / \mathrm{m} . \mathrm{K})\end{array}$} \\
\hline (kJ/kg) & (cal/g) & (kJ/kg.K) & $\left(\mathrm{cal} / \mathrm{g}^{0} \mathrm{C}\right)$ & \\
\hline 386.8 & 92.4 & 0.917 & 0.219 & 238 \\
\hline $\begin{array}{l}\text { Resistivity } \\
(\mu o h m . c m \\
\text { at 200C) }\end{array}$ & $\begin{array}{c}\text { Vol. } \\
\text { change } \\
\text { on } \\
\text { melting } \\
(\%)\end{array}$ & $\begin{array}{l}\text { Density } \\
(\mathrm{g} / \mathrm{cm} 3)\end{array}$ & $\begin{array}{l}\text { Coeff. Of } \\
\text { expansion } \\
(x 10-6 / K)\end{array}$ & $\begin{array}{c}\text { Brinell } \\
\text { hardness } \\
\text { no. }\end{array}$ \\
\hline 2.67 & 6.6 & 2.70 & 23.5 & 17 \\
\hline & ninium & memil & ketahar & terhadap \\
\hline
\end{tabular}

korosi yang baik pada beberapa kondisi lingkungan karena permukaan aluminium mampu membentuk lapisan alumina $\left(\mathrm{Al}_{2} \mathrm{O}_{3}\right)$ bila bereaksi dengan oksigen. Struktur kristal yang dimiliki aluminium adalah struktur kristal FCC (Face Centered Cubic), sehingga aluminium tetap ulet meskipun pada temperatur yang sangat rendah. Keuletan yang tinggi dari aluminium menyebabkan logam tersebut mudah dibentuk atau mempunyai sifat mampu bentuk yang baik.

Seperti logam murni lainnya, aluminium memiliki kekuatan yang rendah dan tidak dapat langsung diaplikasikan karena ketahanan deformasi dan patahnya kurang tinggi. Oleh karena itu perlu adanya penambahan elemen lain ke dalam aluminium. Sifat aluminium tergantung dari interaksi komposisi kimia dan struktur mikro yang berkembang selama solidifikasi, perlakukan panas, dan proses deformasi (untuk produk tempa) [7].

Dapur krusibel digunakan untuk peleburan logam non-besi seperti perunggu, kuningan, paduan seng dan aluminium. Kapasitas dapur umumnya terbatas hanya beberapa ratus pound saja. Dapur krusibel adalah dapur yang paling tua yang digunakan dalam peleburan logam. Dapur ini mempunyai konstruksi paling sederhana. Dapur ini ada yang menggunakan kedudukan tetap dimana penmgambilan logam cair dengan memakai gayung. Dapur ini sangat fleksibel dan serba guna untuk peleburan yang skala kecil dan sedang. Bahan bakar dapur Krusibel ini adalah gas atau bahan bakar minyak karena akan mudah mengawasi operasinya. Ada pula dapur yang dapat dimiringkan sehingga pengambilan logam dengan menampung dibawahnya. Dapur ini biasanya dipakai untuk skala sedang dan skala besar. Dapur Krusibel jenis ini ada yang dioperasikan dengan tenaga listrik sebagai alat pemanasnya yaitu dengan induksi listrik frekuensi rendah dan juga dapat dengan bahan bakar gas atau minyak, sedangkan dapur Krusibel yang memakai burner sebagai alat pemanas dengan kedudukan tetap[8].

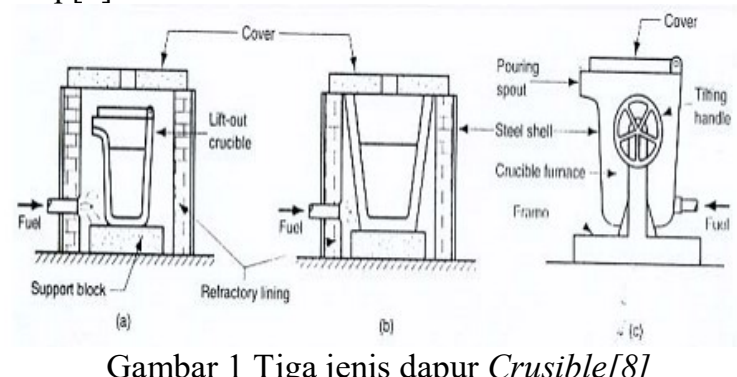

Dalam gambar 1 ditunjukkan tiga jenis dapur krusibel yang biasa digunakan :

a. Krusibel angkat (lift-out krusibel),

b. Pot tetap (stationary pot),

c. Dapur tukik (tilting-pot furnance).

Krusibel angkat yaitu krusibel ditempatkan didalam dapur dan dipanaskan hingga logam mencair. Sebagai bahan bakar digunakan minyak, gas, dan serbuk batubaru. Bila logam telah melebur, krusibel diangkat dari dapur dan digunakan sebagai label penuangan. Dapur pot tetap Dapur tidak dapat dipindah, logam cair diambil dari kontainer dengan ladel. Dapur tukik Dapat ditukik untuk menuangkan logam cair.

\section{METODOLOGI PENELITIAN}

Pada penelitian ini material yang digunakan adalah aluminium sekrap (limbah) yang diperoleh dari pengepul. Peleburan aluminium dilakukan pada temperatur $660 \quad{ }^{0} \mathrm{C}$ selama 1 jam dengan menggunakan dapur crucible. Dalam menyelesaikan penelitian ini, metode yang dilakukan adalah pengujian material hasil peleburan aluminium dan dilakukan kajian pustaka sebagai bahan pertimbangan untuk melihat kemungkinan dilakukan perbaikanperbaikan.

Tempat pengujian; 1) Pengujian kekerasan dilakukan di Laboratorium Teknik Mesin Politeknik Negeri Cilacap 2) Pengujian struktur mikro dilakukan di Laboratorium pengujian logam Universitas Gajah Mada. Pengambilan data pengujian kekerasan posisi 
atas tengah dan bawah, dari data-data hasil pengujian yang dilakukan kemudian dibandingkan dengan data hasil pengujian yang dilakukan pada proses peleburan yang kedua kalinya.

Tabel 2 komposisi kimia aluminium sekrap

\begin{tabular}{|c|c|c|c|c|}
\hline $\mathrm{Al} \%$ & $\mathrm{Zn} \%$ & $\mathrm{Si} \%$ & $\mathrm{Fe} \%$ & $\mathrm{Cu} \%$ \\
\hline 89.52 & 7.71 & 1.84 & 0.489 & 0.146 \\
\hline $\mathrm{Mn} \%$ & $\mathrm{Ni} \%$ & $\mathrm{Ca} \%$ & $\mathrm{Ti} \%$ & $\mathrm{Mg} \%$ \\
\hline 0.491 & 0.035 & 0.0027 & $<0.069$ & $<0.0500$ \\
\hline $\mathrm{Sn} \%$ & $\mathrm{~Pb} \%$ & $\mathrm{Cr} \%$ & $\mathrm{~V} \%$ & $\mathrm{Zr} \%$ \\
\hline$<0.0500$ & $<0.0300$ & $<0.0150$ & $<0.0100$ & $<0.0030$ \\
\hline Sr \% & $\mathrm{Be} \%$ & & & \\
\hline$<0.0005$ & $<0.0001$ & & & \\
\hline
\end{tabular}

\section{Alat dan Bahan}

Tabel 1 Peralatan dan bahan yang digunakan adalah sebagai berikut:

\begin{tabular}{|c|c|c|c|}
\hline No & $\begin{array}{l}\text { Alat dan } \\
\text { Bahan }\end{array}$ & Spesifikasi & Fungsi \\
\hline 1. & $\begin{array}{l}\text { Aluminium } \\
\text { sekrap }\end{array}$ & $\begin{array}{l}\text { Aluminium } \\
\text { skrap }\end{array}$ & $\begin{array}{l}\text { Raw } \\
\text { Material }\end{array}$ \\
\hline 2. & Dapur Crucible & $\begin{array}{l}\text { Dapur } \\
\text { Peleburan } \\
\text { dengan } \\
\text { bahan bakar } \\
\text { gas LPG. }\end{array}$ & $\begin{array}{l}\text { Sebagai alat } \\
\text { peleburan } \\
\text { alumunium } \\
\text { sekrap. }\end{array}$ \\
\hline 3. & Mikroskop optic & $\begin{array}{l}\text { Mikroskop } \\
\text { Olympus } \\
\text { PMEU serta } \\
\text { dengan } \\
\text { kelengkapan } \\
\text { nya }\end{array}$ & $\begin{array}{l}\text { Digunakan } \\
\text { untuk } \\
\text { pengujian } \\
\text { mikro } \\
\text { struktur dari } \\
\text { specimen. }\end{array}$ \\
\hline 4. & $\begin{array}{l}\text { Rockwell } \\
\text { Hardness Tester }\end{array}$ & $\begin{array}{l}\text { Rockwell } \\
\text { Hardness } \\
\text { Tester yang } \\
\text { digunakan } \\
\text { adalah } \\
\text { model } \mathrm{VH} \text { - } \\
150\end{array}$ & $\begin{array}{l}\text { Digunakan } \\
\text { untuk } \\
\text { pengujian } \\
\text { kekerasan. }\end{array}$ \\
\hline
\end{tabular}

\section{HASIL DAN PEMBAHASAN}

Hasil pengujian dan pembahasan dari proses pengecoran skrap aluminium menggunakan dapur crucible dengan pengujian yang dilakukan pada material hasil peleburan, yaitu: struktur mikro dan kekerasan.

\section{a. Pengujian Material}

Pengambilan data hasil struktur mikro adalah menggunakan sampel pengujian dilakukan pada bagian atas, tengah dan bawah pada hasil pengecoran pertama.

Pengambilan data hasil uji kekerasan dilakukan menggunakan alumunium hasil peleburan pertama dan dibandingkan dengan hasil pengujian kekerasan peleburan kedua menggunakan metode Rockwell. Seperti ditunjukkan pada gambar 2 dan 3 berikut untuk material hasil pengecoran dengan dapur crucible.

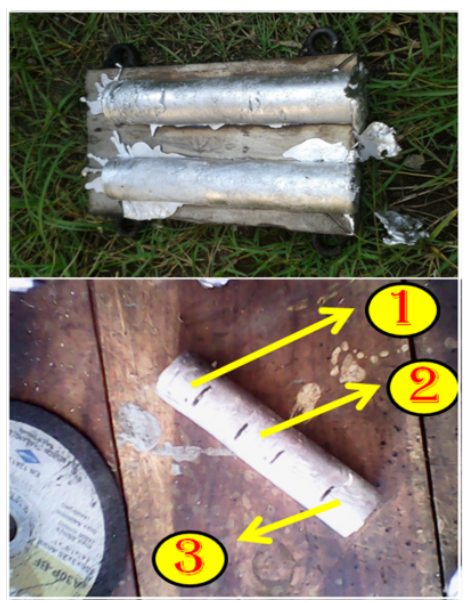

Gambar 2 hasil pengecoran dipotong menjadi tiga bagian

Keterangan gambar:

Bagian 1 (bagian atas) digunakan untuk pengujian setruktur mikro dan pengujian kekerasan.

Bagian 2 (bagian tengah) digunakan untuk pengujian setruktur mikro dan pengujian kekerasan.

Bagian 3 (bagian bawah) digunakan untuk pengujian setruktur mikro dan pengujian kekerasan.

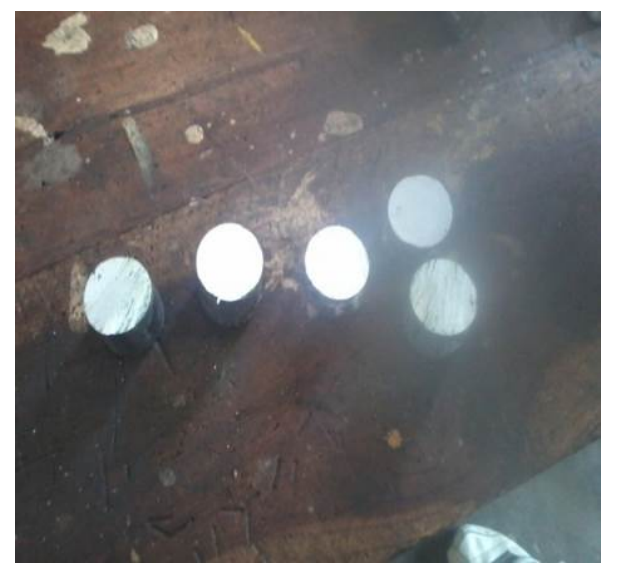

Gambar 3 hasil pemotongan material untuk spesimen pengujian

\section{Hasil Pengujian}


Pengujian struktur mikro dari pengecoran skrap aluminium menggunakan dapur crucible dengan menggunakan mikroskop merk Olympus PMEU dengan perbesaran 50x. Sehingga pada hasil foto diketahui satu strip pada foto adalah 5 mikro.

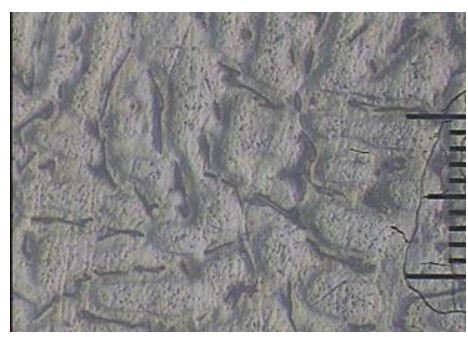

Gambar 4 Spesimen bagian atas (perbesaran 50x)

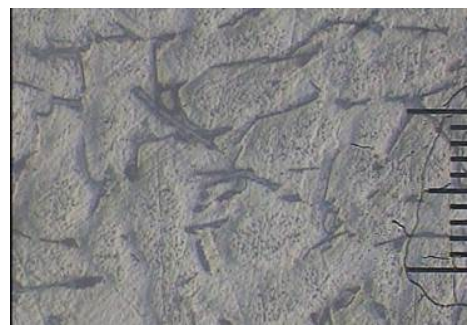

Gambar 5 Spesimen bagian tengah (perbesaran 50x)

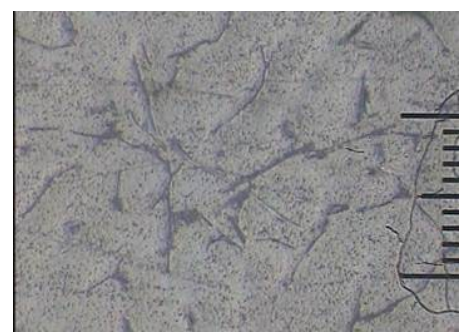

Gambar 6 Spesimen bagian bawah (perbesaran 50x)

Dari gambar 4, 5 dan 6 tiga hasil foto mikro yang dilakukan pada bagian atas, tengah, dan bawah dari hasil pengecoran dengan menggunakan dapur Crucible dimana material menunjukkan hampir semua bagian berwarna putih dimana warna putih pada bagian tersebut adalah fasa $\mathrm{Al}$ (aluminium) $89,52 \%$ dan untuk warna hitam adalah paduan lainnya yang sebagian besar adalah $\mathrm{Si}$ (Silikon) 1,84\% dan $\mathrm{Zn}$ (seng) 7,71\%. Batas butir terlihat tidak beraturan baik di bagian atas, tengah, dan bawah.
Gambar 7 Porositas pada spesimen bagian atas (perbesaran 50x)

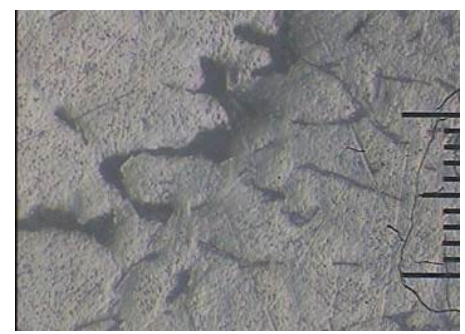

Gambar 8 porositas pada spesimen bagian teng in (perbesaran 50x)

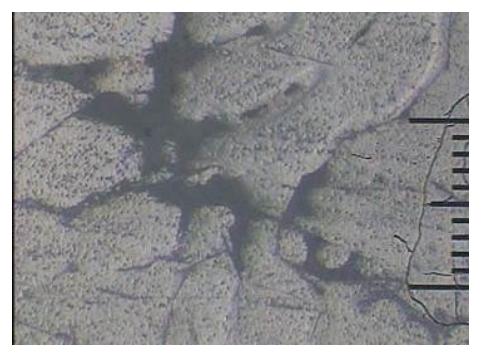

Gambar 9 Porositas pada spesimen bagian bawah (perbesaran 50x)

Gambar 7 menunjukan porositas pada spesimen bagian atas dimana porsitas nilainya terlihat kecil, Gambar 8 menunjukan porositas pada spesimen bagian tengah dimana porsitas nilainya terlihat lebih besar nilainya daripada bagian atas, Gambar 9 menunjukan porositas pada spesimen bagian bawah dimana porsitas terlihat nilainya sangat besar. Kemungkinan porositas material pada bagian bawah terlihat dengan jelas karena nilainya sangat besar dikarenakan banyaknya udara yang terjebak dalam cetakan yang paling banyak ada di bagian bawah cetakan.

Pengujian kekerasan dari proses pengecoran skrap aluminium menggunakan Dapur Crucible menggunakan pengujian Rockwell B. Pengujian dilakukan menggunakan aluminium sekrap yang dilebur sebanyak dua kali pada masing-masing peleburan dilakukan pengujian. Adapun hasil perbandingan pengujian kekerasan dapat dilihat pada gambar 10 .

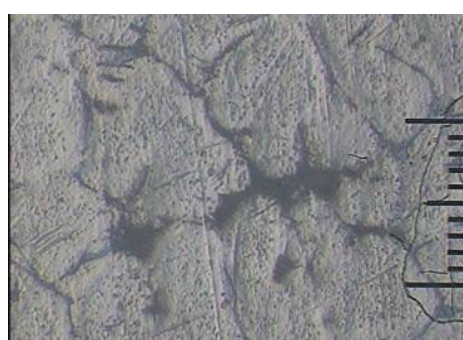




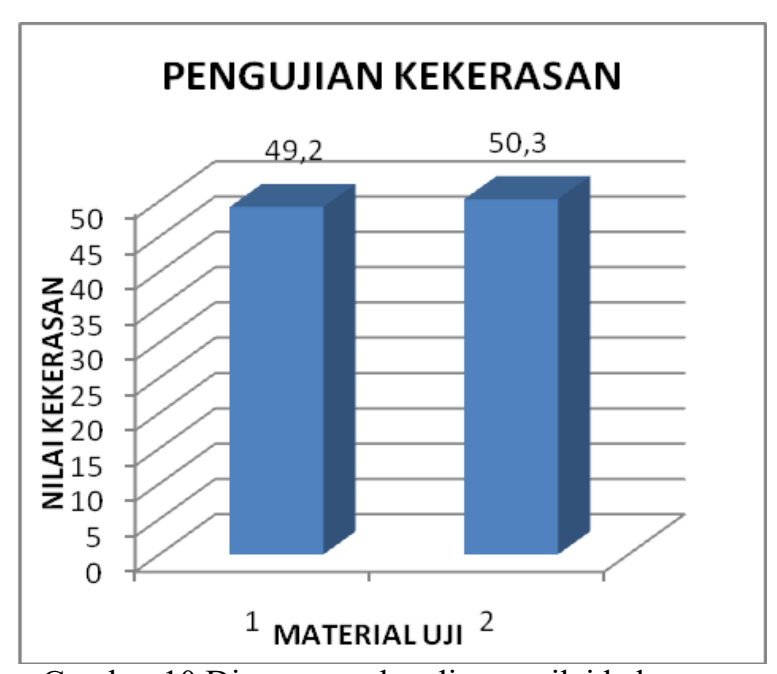

Gambar 10 Diagram perbandingan nilai kekerasan Dari pengujian kekerasan menggunakan metode Rockwell $B$ diperoleh nilai rata-rata kekerasan pada pengecoran pertama adalah 49,2 HRB dan pengecoran kedua 50,3 HRB mengalami perubahan kekerasan sedikit dimana pada peleburan kedua nilai kekerasannya meningkat lebih baik. Sedangkan seperti diketahui Alumunium hasil pengecoran menggunakan unsur paduan utamanya menggunakan Seng ( $\mathrm{Zn}$ ) diketahui umumnya akan meningkatkan sifat-sifat mekanik pada perlakuan panas, juga kemampuan mesin. Akan tetapi efek merugikan seng lainnya adalah menurunkan kemampuan cor, meningkatkan kecenderungan terjadinya stress corrosion cracking, shrinkage, dan retak karena panas.

\section{KESIMPULAN}

Dari pengujian yang telah dilakukan maka diambil kesimpulan sebagai berikut:

1. Foto hasil struktur mikro menunjukkan bahwa kondisi paling baik diperoleh pada material bagian atas akan tetapi pada bagian bawah terjadi porositas yang besar seperti yang telah terlihat pada foto mikro dikarenakan banyaknya udara yang terjebak dalam cetakan ada di bagian bawah cetakan. Hasil pengujian kekerasan menggunakan metode Rockwell nilai rata-rata masing-masing pengecoran pertama adalah 49,2 HRB dan pengecoran kedua 50,3 HRB.

2. Dapur Crucible yang digunakan sebagai alat pelebur aluminium sekrap tidak mempengaruhi sifat fisis dan mekanik hasil peleburan.

\section{DAFTAR PUSTAKA}

[1] Budiono, A., Widayat, W., Rusiyanto. 2010, "Peningkatan Sifat Mekanis Sekrap Aluminium Dengan Degassing”, Universitas Negeri Semarang.

[2] Purnomo, 2004, Pengaruh Pengecoran Ulang Terhadap Kekuatan tarik dan Ketangguhan Impak pada Paduan Aluminium 320, Jurnal Proceedings, Komputer dan Sistem Intelijen Auditorium Universitas Gunadarma, Jakarta hal 905-911.

[3] Setiawan, Hera; 2014. "Pengujian Kekerasan dan Komposisi Kimia Produk Cor Propeler Aluminium"; Prosiding SNST ke-5 Unwahas, 31-36.

[4] Titiek D., Rusnaldy., Gunawan DH., 2014. "Pembuatan Bahan Standar AlSi12 dari Skrap Aluminium, Studi Komposisi Kimia, Porositas, dan Sifat Kekerasan Bahan"; SNATIF Ke -1 Fakultas Teknik - Universitas Muria Kudus.

[5] Suyanto, Kurniawan D. R, Wibowo R; 2016. "ADC3 yang Dibuat dengan Peleburan Ulang Aluminium Bekas Sebagai Bahan Propeler Kapal Kayu"; SIMETRIS, Vol 7 No 2.

[6] John R. Brown,. 1994, Feseco Non-Ferrous Foundryman's Handbook Eleventh edition Revised and edited.

[7] Totten, George. E, 1999, Handbook of Aluminium, Vol. 1, Marcel Dekker, New York, Bassel.

[8] Groover, M., 2000, Fundemental of Modern Manufacturing, Bradley University, New York. 